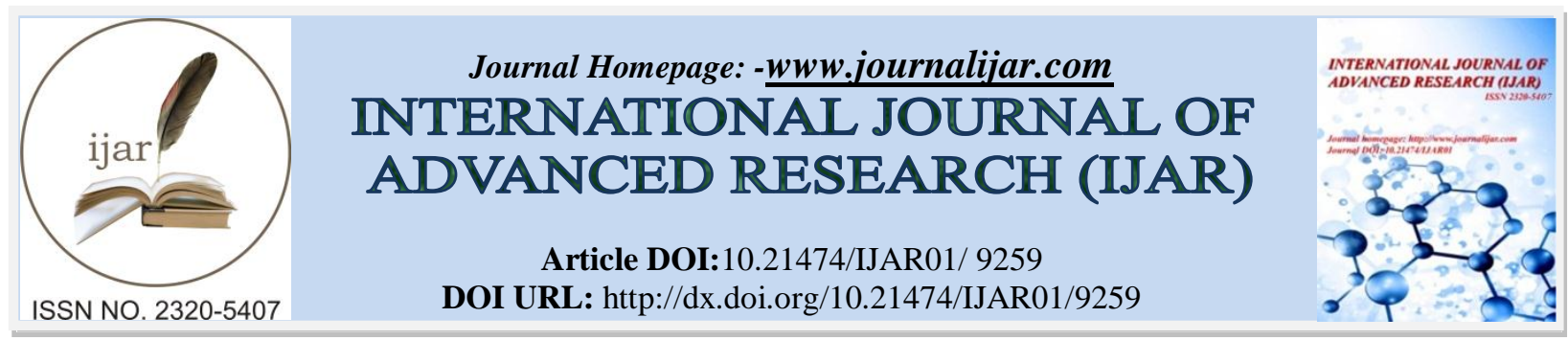

RESEARCH ARTICLE

\title{
EFFICACY OF SELF INSTRUCTIONAL MODULE (SIM) ON KNOWLEDGE OF MOTHERS REGARDING PREVENTION OF WORM INFESTATION AMONG SCHOOL CHILDREN.
}

\author{
Pooja Rani. \\ Department of Paediatric Nursing, Shri Mata Vaishno Devi College of Nursing, Shri Mata Vaishno Devi University \\ (Kakryal), Katra, J\&K.
}

\section{Manuscript Info}

Manuscript History

Received: 12 April 2019

Final Accepted: 14 May 2019

Published: June 2019

Key words:-

Infestation, School Children,

Helminthes.

\section{Abstract}

Background: Invasion of humans by worms, or worm Infestation is a worldwide public health problem. One third of the world's population is infected with one or more species of intestinal helminthes. Aim: Primary objective of the study was to assess the efficacy of Self Instructional Module (SIM) on knowledge of mothers regarding prevention of worm infestation among school children aged 6-12 yr, at Panthal, District Reasi, J \& K. Secondary objective was to find the association between pre-test knowledge score of mothers with their selected demographic variables. Methods: A quantitative research approach was used and data was collected from 50 mothers with purposive sampling technique. Self instructional module was prepared and structured questionnaire was used to collect the data from the selected samples. Result: The Mean \pm SD pre-test score $(9.02 \pm 3.298)$ of knowledge of mothers was lesser than the Mean \pm SD post-test score (15.92 \pm 4.134). The calculated ' $z$ ' value of 9.23 was found to be statistically significant at 0.05 level of significance. Conclusion: SIM was found to be very effective to improve knowledge of mothers regarding worm infestation in school children. It was inferred from the study that only mother's age, education and latrine facility in the house were associated with the knowledge of mothers.

Copy Right, IJAR, 2019,. All rights reserved.

\section{Introduction:-}

Childhood holds a very important place in the life of every human being. Children are tomorrow's citizens. Worm infestation is a major public health problem in children of developing countries because of poor socio-economic conditions and lack of good hygienic livings.

Two billion people worldwide and 400 million school-age children are affected by parasitic worms. 300 million of those infected suffer severe illness, and over 150,000 die annually. WHO recommends annual treatment in areas where prevalence rate of soil-transmitted helminthiases is between $20 \%$ and $50 \%$, and, a bi-annual treatment in areas with prevalence rates of over 50 .

Worm infestation is the infection of intestinal tract with any of several species of helminthes or parasitic worms, including Ascaris (Round worm), Entrobius (Pin worm), Trichinella spiralis and various species of Cestodes (Tape 
worm). Round worm enter the body through contaminated food and drinking water, the tape worm on the other hand through raw or uncooked meat and also through the faecal matter. Hookworm enters the body through when one walks with bare foot on an infected land. Worms infestation is one of the major causes of childhood malnutrition, anaemia, stunted physical and mental growth, psycho-social problems. It also causes recurrent gastrointestinal and upper respiratory tract infection contributing to high morbidity and mortality in children. The World Health Organization estimates that over one billion of the world's population is chronically infested with soil transmitted helminthes. Worm infestation remains one of the main problems of child development.

\section{Material And Methods:-}

A quantitative research approach was used to assess the efficacy of Self Instructional Module (SIM) on knowledge of mothers regarding prevention of worm infestation among school children aged 6-12 yrs. The research design adopted for the study was Non-experimental research design. The target population for the study was mothers of school going children at Village Panthal, Jammu \& Kashmir. 50 mothers of school going children were selected with purposive sampling technique for the present study. A self instructional module was prepared and structured questionnaire was used to collect the data from the selected samples. Tool consisted of two parts including selected demographic variables of mothers and 25 questions to assess knowledge of mothers regarding prevention of worm infestation in school children. For each correct answer score ' 1 ' was given and for the wrong answer score was ' 0 '.

\begin{tabular}{|c|c|c|}
\hline S. No. & Level of knowledge & Score \\
\hline 1. & Adequate & $21-25$ \\
\hline 2. & Moderate & $8-20$ \\
\hline 3. & Inadequate & $0-7$ \\
\hline
\end{tabular}

Analysis was done by using descriptive measures (frequency and percentage, Mean and Standard deviation) and inferential statistics by Chi-square. ' $z$ '-value was calculated to determine the difference in pre test and post test knowledge score of mothers.

\section{Result:-}

Demographic variable description

Table 1:-Frequency and percentage distribution of mothers according to demographic variables.

\begin{tabular}{|c|c|c|c|}
\hline \multicolumn{2}{|c|}{ Demographic variables } & \multirow{2}{*}{$\begin{array}{l}\mathbf{N} \\
2\end{array}$} & \multirow{2}{*}{$\begin{array}{l}\% \\
4 \\
\end{array}$} \\
\hline \multirow{4}{*}{ Age of mother } & $<25$ yrs & & \\
\hline & $26-30 \mathrm{yrs}$ & 18 & 36 \\
\hline & $31-35$ yrs & 16 & 32 \\
\hline & $>35$ yrs & 14 & 28 \\
\hline \multirow[t]{4}{*}{ Education of mother } & Illiterate & 5 & 10 \\
\hline & Primary & 17 & 34 \\
\hline & Matriculate & 19 & 38 \\
\hline & Graduate & 9 & 18 \\
\hline \multirow[t]{4}{*}{ Occupation of mother } & Private job & 3 & 6 \\
\hline & Govt. job & 7 & 14 \\
\hline & Self working & 14 & 28 \\
\hline & Housewife & 26 & 52 \\
\hline \multirow{4}{*}{$\begin{array}{c}\text { Number of school children in } \\
\text { the family }\end{array}$} & 1 & 7 & 14 \\
\hline & 2 & 16 & 32 \\
\hline & 3 & 18 & 36 \\
\hline & $>3$ & 9 & 18 \\
\hline \multirow[t]{2}{*}{ Dietary pattern } & Vegetarian & 28 & 56 \\
\hline & Non- Vegetarian & 22 & 44 \\
\hline \multirow[t]{2}{*}{ Latrine facility } & Indoor & 34 & 68 \\
\hline & Outdoor & 16 & 32 \\
\hline \multirow[t]{2}{*}{ Pet animal in house } & Yes & 22 & 44 \\
\hline & No & 26 & 52 \\
\hline
\end{tabular}


Comparison Of Mean, Pre Test And Post Test Knowledge Scores Of Mothers

Table 2:-Comparison of mean, pre and post test scores

\begin{tabular}{|c|c|c|c|c|c|c|}
\hline $\begin{array}{c}\text { Knowledge } \\
\text { Scores }\end{array}$ & Mean & SD & \multirow{2}{*}{ SE } & \multicolumn{2}{|c|}{ ' $Z$ ' Value } & \multirow{2}{*}{ Inference } \\
\cline { 5 - 6 } & & & & $\begin{array}{c}\text { Calculated } \\
\text { Value }\end{array}$ & Table Value & \\
\hline Pre Test & 9.02 & 3.298 & & & & \multirow{2}{*}{$\mathrm{S}^{*}$} \\
\hline Post Test & 15.92 & 4.134 & 0.747 & 9.23 & 2.0 & \\
\hline
\end{tabular}

*Significant at p-value $<0.05$

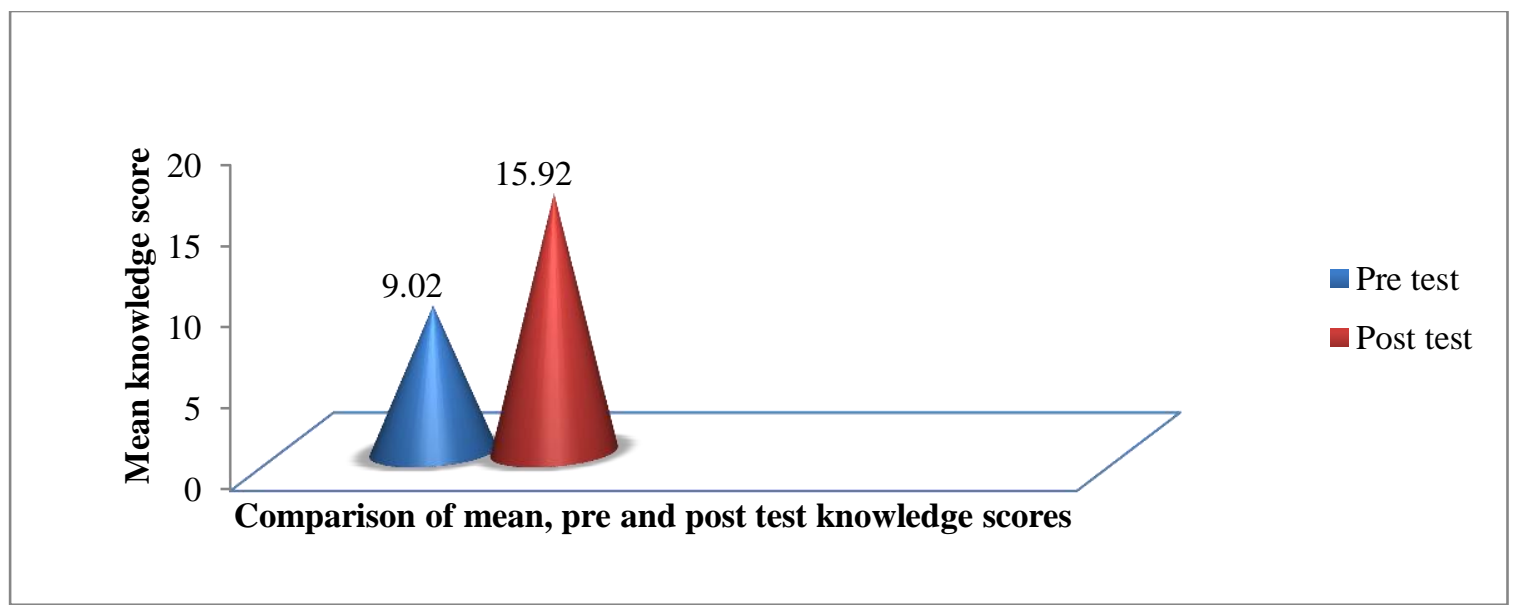

Figure 1:-Comparison of mean, pre and post test scores among mothers of school aged children

The data presented in the table no. 2 and figure no. 1 depicts that the Mean \pm SD pre-test score $(9.02 \pm 3.298)$ of knowledge of mothers was lesser than the Mean \pm SD post-test score (15.92 \pm 4.134$)$. The calculated ' $z$ ' value of 9.23 was found to be statistically significant at 0.05 level of significance. Therefore it can be interpreted that there was significant difference between pre test and post test knowledge score of mothers regarding prevention of worm infestation among school children aged 6-12 years.

Association Between Demographic Variables And Knowledge of Mothers

Table 3:-Association between selected demographic variables and knowledge of mothers

\begin{tabular}{|c|c|c|c|c|c|c|c|c|}
\hline \multicolumn{2}{|c|}{ Demographic variables } & \multicolumn{3}{|c|}{ Level of knowledge } & df & \multirow{5}{*}{\begin{tabular}{|l|}
$\begin{array}{l}\text { Table } \\
\text { value }\end{array}$ \\
12.59 \\
\end{tabular}} & \multirow{5}{*}{$\begin{array}{c}\begin{array}{c}\text { Chi } \\
\text { calculated } \\
\text { value }\end{array} \\
21.854 \\
\end{array}$} & \multirow{2}{*}{$\begin{array}{c}\text { Inference } \\
S^{*}\end{array}$} \\
\hline \multirow{4}{*}{$\begin{array}{l}\text { Age of } \\
\text { mother }\end{array}$} & $<25 \mathrm{yrs}$ & $\begin{array}{c}\text { Adequate } \\
0 \\
\end{array}$ & $\begin{array}{c}\text { Moderate } \\
0 \\
\end{array}$ & $\begin{array}{c}\text { Inadequate } \\
2 \\
\end{array}$ & 6 & & & \\
\hline & $26-30 \mathrm{yrs}$ & 0 & 1 & 17 & \multirow{3}{*}{0} & & & \\
\hline & $31-35$ yrs & 2 & 7 & 7 & & & & \\
\hline & $>35$ yrs & $\mathrm{O}$ & 10 & 4 & & & & \\
\hline \multirow{4}{*}{$\begin{array}{l}\text { Education of } \\
\text { mother }\end{array}$} & Illiterate & 0 & 5 & 0 & \multirow[t]{4}{*}{6} & \multirow[t]{4}{*}{12.59} & \multirow[t]{4}{*}{16.436} & \multirow[t]{4}{*}{$\mathrm{S}^{*}$} \\
\hline & Primary & 2 & 7 & 8 & & & & \\
\hline & Matriculate & 0 & 4 & 15 & & & & \\
\hline & Graduate & 0 & 2 & 7 & & & & \\
\hline \multirow{4}{*}{$\begin{array}{l}\text { Occupation } \\
\text { of mother }\end{array}$} & Private job & 0 & 1 & 2 & \multirow[t]{4}{*}{6} & \multirow[t]{4}{*}{12.59} & \multirow[t]{4}{*}{7.433} & \multirow[t]{4}{*}{ NS } \\
\hline & Govt. job & 1 & 1 & 5 & & & & \\
\hline & $\begin{array}{c}\text { Self } \\
\text { working }\end{array}$ & 1 & 3 & 10 & & & & \\
\hline & Housewife & 0 & 13 & 13 & & & & \\
\hline \multirow{4}{*}{$\begin{array}{l}\text { Number of } \\
\text { school } \\
\text { children in } \\
\text { the family }\end{array}$} & 1 & 0 & 3 & 4 & \multirow[t]{4}{*}{6} & \multirow[t]{4}{*}{12.59} & \multirow[t]{4}{*}{8.257} & \multirow[t]{4}{*}{ NS } \\
\hline & 2 & 0 & 4 & 12 & & & & \\
\hline & 3 & 2 & 5 & 11 & & & & \\
\hline & $>3$ & 0 & 6 & 3 & & & & \\
\hline Dietary & Vegetarian & 2 & 10 & 16 & 2 & 5.99 & 5.115 & NS \\
\hline
\end{tabular}




\begin{tabular}{|c|c|c|c|c|c|c|c|c|}
\hline pattern & $\begin{array}{c}\text { Non- } \\
\text { Vegetarian }\end{array}$ & 0 & 8 & 14 & & & & \\
\hline \multirow{2}{*}{$\begin{array}{l}\text { Latrine } \\
\text { facility }\end{array}$} & Indoor & 2 & 16 & 16 & \multirow[t]{2}{*}{2} & \multirow[t]{2}{*}{5.99} & \multirow[t]{2}{*}{6.605} & \multirow[t]{2}{*}{$\mathrm{S}^{*}$} \\
\hline & Outdoor & 0 & 2 & 14 & & & & \\
\hline \multirow{2}{*}{$\begin{array}{c}\text { Pet animal } \\
\text { in house }\end{array}$} & Yes & 1 & 7 & 14 & \multirow[t]{2}{*}{2} & \multirow[t]{2}{*}{5.99} & \multirow[t]{2}{*}{0.470} & \multirow[t]{2}{*}{ NS } \\
\hline & No & 1 & 11 & 16 & & & & \\
\hline
\end{tabular}

$(\mathrm{P}=0.05)$ NS-Non Significance, df-degree of freedom, $\mathrm{S} *$-Significance

Table no. 3 depicts that at 5\% level of significance, selected demographic variables i.e., age of the mother, education of the mother and latrine facility in the house, were found significantly associated with the knowledge of mothers regarding prevention of worm infestation among school children aged 6-12 years.

\section{Discussion:-}

The data collected were grouped and analyzed by using descriptive and inferential statistical methods. Tables and figures were used to explain the demographic variables and knowledge of mothers of school children aged 6-12 years. Result revealed that majority of mothers were in the age group of 26-30 years (36\%) and were matriculate (38\%) in education. 52\% of mothers were housewife and $36 \%$ were having 3 school children in the family. Majority of mothers were vegetarian (56\%) and had indoor latrine facility (68\%) in the house. 52\% of mothers were not having any pet animal in the house.

The Mean \pm SD pre-test score $(9.02 \pm 3.298)$ of knowledge of mothers was lesser than the Mean \pm SD post-test score (15.92 \pm 4.134). The calculated ' $z$ ' value of 9.23 was found to be statistically significant at 0.05 level of significance. Therefore it can be interpreted that there was significant difference between pre test and post test knowledge score of mothers regarding prevention of worm infestation among school children aged 6-12 years. It was found that there was statistically significant association between the pre test knowledge scores and demographic variables of mother's i.e., Age, Education and Latrine facility in the house.

\section{Conclusion:-}

The major conclusion of the study drawn on the basis of the findings of the study was that there was significant difference between pre test and post test knowledge scores of mothers. It is concluded that SIM was found to be very effective to improve knowledge of mothers regarding prevention of worm infestation in school children. It was inferred that only mother's age, education and latrine facility in the house were associated with the knowledge of mothers.

\section{References:-}

1. Intestinal worms in humans and their symptoms: https://www.medicalnewstoday.com/articles/324042.php

2. Kids health from nemours : https://kidshealth.org/en/parents/ascariasis.html

3. Homo sapiens diseases - metazoa - helminths : http://www.ufrgs.br/imunovet/molecular_immunology/pathohomoeumetazoa.html

4. Prevalence of intestinal worm infestation and efficacy of anthelminthic drugs: https://www.ncbi.nlm.nih.gov/pmc/articles/PMC4017176/

5. Tapeworms in humans: https://www.webmd.com/digestive-disorders/tapeworms-in-humans\#1

6. Health encyclopedia: https://www.urmc.rochester.edu/encyclopedia/content.aspx?ContentTypeID=160\&ContentID=54

7. Worm infestations, Apollo clinic: https://www.apolloclinic.com/forpatients/services/consultations/paediatrics/worm-infestations?/worm-infestations

8. Worm infestation in children, aap news and journals :https://pedsinreview.aappublications.org/content/36/8/341. 